Texas A\&M University-San Antonio

Digital Commons @ Texas A\&M University- San Antonio

\title{
Suffer the Little Children to Come: The Legal Rights of Unaccompanied Alien Children under United States Federal Court Jurisprudence
}

Claire Nolasco

Texas A\&M University-San Antonio, Claire.Nolasco@tamusa.edu

Daniel Braaten

Texas Lutheran University

Follow this and additional works at: https://digitalcommons.tamusa.edu/crim_faculty

Part of the Civil Rights and Discrimination Commons, Criminology and Criminal Justice Commons, and the Immigration Law Commons

\section{Repository Citation}

Nolasco, Claire and Braaten, Daniel, "Suffer the Little Children to Come: The Legal Rights of Unaccompanied Alien Children under United States Federal Court Jurisprudence" (2019). Criminology and Criminal Justice Faculty Publications. 2.

https://digitalcommons.tamusa.edu/crim_faculty/2

This Article is brought to you for free and open access by the College of Arts and Sciences at Digital Commons @ Texas A\&M University- San Antonio. It has been accepted for inclusion in Criminology and Criminal Justice Faculty Publications by an authorized administrator of Digital Commons @ Texas A\&M University- San Antonio. For more information, please contact deirdre.mcdonald@tamusa.edu. 


\section{OXFORD}

\section{International Journal of Refugee Law}

\section{Suffer the Little Children to Come: Legal Rights of Unaccompanied Alien Children under United States Federal Court Jurisprudence}

\begin{tabular}{|r|l|}
\hline Journal: & International Journal of Refugee Law \\
\hline Manuscript ID & IJRL-2018-010 \\
\hline Manuscript Type: & Original Manuscript \\
\hline Keywords: & unaccompanied alien children, unaccompanied minors, immigration \\
\hline
\end{tabular}




\title{
Suffer the Little Children to Come: Legal Rights of Unaccompanied Alien Children under United States Federal Court Jurisprudence
}

\begin{abstract}
This article analyzes United States ('U.S.') federal court jurisprudence to determine the legal rights of unaccompanied alien children in various stages of immigration enforcement proceedings. After briefly discussing statistics on unaccompanied alien children in the U.S., it explains the legal context of U.S. laws governing unaccompanied minors. Through examining 36 cases decided by the 12 U.S. Circuit Courts of Appeals, the article specifies how the federal courts interpreted and expanded on the legal rights of unaccompanied alien children upon apprehension by immigration officials, during placement or detention decisions of the Office of Refugee Resettlement, prior to voluntary departure, during asylum proceedings, when rearrested after release, and while released pending immigration proceedings. According to the U.S. federal courts, the government must grant unaccompanied alien children procedural due process if it denies their release to the custody of an available and willing legal custodian. Case law examining the rights of UAC prior to voluntary departure emphasize the need to grant them the opportunity to consult with a responsible adult, including a lawyer from a free legal services list that should be provided to them. Federal courts have also tackled issues concerning asylum claims filed by UAC. These include the right of third parties to custody of the unaccompanied minor, the minority age at the time of the asylum application, and the right of the UAC to request consent for a state juvenile court's jurisdiction. In removal proceedings against UAC, federal courts have elaborated on the scope and meaning of the right to counsel and the right to a bond rehearing upon their rearrest because of allegations of gang membership. Finally, federal courts
\end{abstract}


have also examined issues concerning the rights of the unaccompanied alien child while detained in ORR facilities and while in U.S. territory

\section{Introduction}

The recent surge of unaccompanied alien children ('UAC') over the last few years has raised complex legal issues regarding how and when the UAC should be detained upon apprehension in the United States ('U.S'.), who they should be released to, and what rights they should be accorded in immigration enforcement proceedings. ${ }^{1}$ These legal issues exist in the context of broader political debates ongoing in the U.S. over levels of immigration and possible large-scale reforms to U.S. immigration policy. ${ }^{2}$ In addition to the legal questions UAC present for U.S. immigration policy, they present significant ethical questions. ${ }^{3}$

UAC are particularily vulnerable since by definition they are children, traveling alone and undocumented, into a country not their own. ${ }^{4}$ Many of these children are fleeing violence and extreme poverty in their home countries. ${ }^{5}$ Three primary source countries of UAC to the U.S-El Salvador, Guatemala, and Honduras-have high levels of extreme poverty and

${ }^{1}$ Catalina Amuedo-Dorantes and Thitima Puttitanun, 'Undocumented Youth in Limbo: The Impact of America's Immigration Enforcement Policy on Juvenile Deportations' (2018) 31 Journal of Population Economics 597; Claire Nolasco, 'Models of legal representation for unaccompanied minors' (2018) 54 Criminal Law Bulletin 274; Wendy Shea, 'Almost there: Unaccompanied Alien Children, Immigration Reform, and a Meaningful Opportunity to Participate in the Immigration Process' (2014) 18 UC Davis Journal of Juvenile Law \& Policy 148.

${ }^{2}$ Eliana Corona, 'The Reception and Processing of Minors in the United States in Comparison to that of Australia and Canada: Would Being a Party to the UN Convention on the Right of the Child Make a Difference in U.S. Courts?' (2017) 40 Hastings International and Comparative Law Review 205; Rebeca G. Gil, 'Running into the arms of expatriation: America's failure addressing the rights of unaccompanied migrant children from central America' (2017) 32 Maryland Journal of International Law 346.

${ }^{3}$ Lilian Chavez and Cecilia Menjívar, 'Children without Borders: A Mapping of the Literature on Unaccompanied Migrant Children to the United States' (2010) 5 Migraciones Internacionales 71; Shani King, 'Alone and Unrepresented: A Call to Congress to Provide Counsel for Unaccompanied Minors' (2013) 50 Harvard Journal On Legislation 331.

${ }^{4}$ Shani King, 'Alone and Unrepresented: A Call to Congress to Provide Counsel for Unaccompanied Minors' (2013) 50 Harvard Journal On Legislation 331; McKayla M. Smith, 'Scared, But No Longer Alone: Using Louisiana to Build a Nationwide System of Representation for Unaccompanied Children' (2017) 63 Loyola Law Review 111. ${ }^{5}$ Catalina Amuedo-Dorantes and Thitima Puttitanun, 'DACA and the Surge in Unaccompanied Minors at the USMexico Border' (2016) 54 International Migration 102; Serap Keles, Oddgeir Friborg, Thormod Idsoe, Selcuk Sirin, and Brit Oppedal, 'Resilience and Acculturation Among Unaccompanied Refugee Minors' (2018) 42 International Journal of Behavioral Development 52. 
violence, ${ }^{6}$ and have a proliferation of international criminal gangs that target and victimize many UAC. $^{7}$ Additionally, many UAC come to the U.S. seeking reunification with family members, mostly parents, who have emigrated earlier. ${ }^{8}$ These factors motivating UAC to leave their home country and enter the U.S. underlie the legal questions regarding how justice is given to UAC when they enter into the U.S. immigration system. The complexity of immigration proceedings, especially for a class of noncitizens who are vulnerable to the inherent coercive nature of the proceedings, necessitate an analysis of the legal issues surrounding UAC. ${ }^{9}$

Before turning to the legal analysis however, we present some descriptive statistics on the recent number of UAC who have entered the U.S. and their source countries. Overall, the number of UAC entering the U.S. has grown. Data from the Customs and Border Patrol ('CBP') and the Office of Refugee Resettlement ('ORR') documents the increase over the last few years. Figure 1. presents the number of UAC apprehended per fiscal year. In 2010 and 2011 there were 18,622 and 16,067 UAC apprehended respectively. There was a significant increase for the next few years in 2012, 2013, and 2014 with 24,481, 38,833, and 68,631 UAC apprehended respectively. The numbers decline in 2015 to 40,035 apprehended but increase to 59,757 in 2016 and decline again in 2017 to 41,456 UAC apprehended. Coinciding with the number of UAC who have been apprehended entering the U.S., the number of UAC referred to the Office of Refugee Resettlement has also increased. Figure 1 presents referrals to ORR which is the agency

\footnotetext{
${ }^{6}$ Julie Marzouk, 'Ethical and Effective Representation of Unaccompanied Immigrant Minors in Domestic ViolenceBased Asylum Cases' 2016) 22 Clinical Law Review 395; Cheryl B. Sawyer and Judith Márquez, 'Senseless Violence Against Central American Unaccompanied Minors: Historical Background and Call For Help' (2017) 151 Journal of Psychology 69.

${ }^{7}$ William A. Kandel, Andorra Bruno, Peter J. Meyer, Clare R. Seelke, Maureen Taft-Morales, and Ruth E. Wasem, 'Unaccompanied Alien Children: Potential Factors Contributing to Recent Immigration' (2014) Congressional Research Service $<$ https://fas.org/sgp/crs/homesec/R43628.pdf $>$ accessed 20 January 2018

${ }^{8}$ Marcela Sotomayor-Peterson and Martha Montiel-Carbajal, 'Psychological and Family Well-Being of Unaccompanied Mexican Child Migrants Sent Back From the U.S. Border Region of Sonora-Arizona' (2014) 36 Hispanic Journal of Behavioral Sciences 111.

${ }^{9}$ Danuta Villarreal, 'To Protect the Defenseless: The Need for Child-Specific Substantive Standards for Unaccompanied Minor Asylum-Seekers’ (2004) 26 Houston Journal of International Law 743.
} 
responsible for detaining and sheltering UAC while they await their immigration hearing. The highpoint in referrals was 2016 when 59,170 UAC were referred and the second highest was 2014 when 57,496 were referred. Finally, Figure 1 presents information for three years of ORR UAC sponsorship. Sponsorship will be discussed in more detail below but overall it refers to the practice of ORR releasing a UAC to a family member or other qualified adult who is able to care for them. In 201527,840 UAC were released to sponsors, in 201652,147 were released to sponsors, and in 201742,416 were released to sponsors.

Figure 1 Here

Figure 2. presents information on the country of origin of UAC from FY 2012 to FY 2017. As the figure shows, the vast majority of UAC come from three countries in particular: El Salvador, Guatemala, and Honduras. From 2012 to 2017 the number of UAC from El Salvador gradually increased with 27 percent of the overall total to 34 percent of the overall total in 2016 , although the number did drop back to 27 percent in 2017. UAC from Guatemala also increased as a percentage of the overall total. In 2012 UAC from Guatemala represented 34 percent of all UAC that year and by 2017 that number had increased to 45 percent. Conversely, the number of UAC from Honduras has declined as a percentage of the overall total. In 2012 UAC from Honduras represented 27 percent of the overall total but by 2017 that number had dropped to 23 percent. This small snapshot of the total number of UAC who have entered the U.S. and where they are coming from provides important background and context for the legal analysis that follows.

Figure 2 Here

\subsection{Legal context of U.S. immigration laws on unaccompanied alien children}


Prior to 2003, the Immigration and Naturalization Service ('INS') of the Department of Justice ('DOJ') was responsible for the care and custody of UAC arrested in the U.S. who were suspected of being deportable and who had no responsible parent or legal guardian. ${ }^{10}$ The INS were also tasked with prosecuting removal proceedings against UAC in immigration courts. Over the past decade, an increased number of arrested UAC could not be released on bond or recognizance because INS could not determine whether any person was available to provide care pending deportation proceedings. ${ }^{11}$

In response to the increased flow of UAC into California, the INS Western Regional Office adopted a policy of limiting the release of detained minors to 'a parent or lawful guardian', except in 'unusual and extraordinary cases' allowing release to 'a responsible individual' who agrees to provide for the care, welfare, and wellbeing of the child. ${ }^{12}$ Four UAC filed a class action in the District Court for the Central District of California on behalf of all aliens under the age of 18 detained by the INS Western Region because a parent or legal guardian failed 'to personally appear to take custody of them' ${ }^{13}$ Pending litigation, INS adopted a modified rule allowing alien juveniles to be released to a: (1) parent; (2) legal guardian; or (2) adult relative (e.g., brother, sister, aunt, uncle, grandparent), unless the INS determined that detention was necessary to ensure the UAC's safety or appearance in deportation proceedings. ${ }^{14}$

The district court in Reno v. Flores later approved a consent decree that settled all claims regarding UAC's detention conditions (the 'Flores Settlement'). ${ }^{15}$ The Flores Settlement

\footnotetext{
${ }^{10}$ D.B. v. Cardall 826 F.3d 721 (4th Cir. 2016).

${ }^{11}$ Reno v. Flores 507 U.S. 292 (1993).

${ }^{12}$ ibid. 296.

${ }^{13}$ ibid.

${ }^{14}$ ibid. 297.

${ }^{15}$ Reno (n11).
} 
established a nationwide policy for the detention, release, and treatment of UAC. ${ }^{16}$ Among others, it: (1) defined a 'minor' as 'any person under the age of eighteen (18) years detained in the legal custody of the INS; (2) supported 'family reunification;' (3) listed the preferred order of individuals to whom detained minors may be released; and, (4) provided for the custody and right to a bond hearing of minors who cannot be immediately released. ${ }^{17}$

The Flores Settlement is binding on all successor agencies to the INS, including the Office of Refugee Resettlement ('ORR') of the Department of Health and Human Services ('HHS'). ${ }^{18}$ The Flores Settlement provided that unless detention was necessary to ensure a child's safety or his appearance in immigration court, he must be released without unnecessary delay to a parent or legal guardian. ${ }^{19}$ Juveniles who are not released must, within 72 hours of arrest, be placed in juvenile care facilities that 'meet or exceed state licensing requirements for the provision of services to dependent children'. ${ }^{20}$ Studies indicate that the mental health of UAC depend on the degree of trauma and acculturation upon migration into the country of refuge. ${ }^{21}$ Hence, the necessity of release and placement is essential to the wellbeing of the UAC. ${ }^{22}$

Since the Flores Settlement, Congress enacted the 2002 Homeland Security Act (the

\footnotetext{
${ }^{16}$ D.B. (n10); Flores v. Sessions 862 F.3d 863 (9th Cir. 2017); Elizabeth Lincoln, 'The Fragile Victory for Unaccompanied Children's Due Process Rights After Flores v. Sessions’ (2017) 45 Hastings Constitutional Law Quarterly 157.

${ }^{17}$ Flores (n16) 869.

${ }^{18}$ D.B. (n10).

${ }^{19}$ D.B. (n10); Lincoln (n16).

${ }^{20}$ Reno (n11) 292.

${ }^{21}$ Tammy. M. Bean, Elisabeth Eurelings-Bontekoe and Philip Spinhoven, 'Course and Predictors of Mental Health of Unaccompanied Refugee Minors in the Netherlands: One Year Follow-Up' (2007) 64 Social Science \& Medicine 1204; Israel Bronstein and Paul Montgomery, 'Psychological Distress in Refugee Children: A Systematic Review' (2011) 14 Clinical Child and Family Psychology Review 44; Tine K. Jensen, Envor M. Skårdalsmo, and Krister. W. Fjermestad, 'Development of Mental Health Problems-A Follow-Up Study of Unaccompanied Refugee Minors' (2014) 8 Child \& Adolescent Psychiatry \& Mental Health 1; Serap Keles, Oddgeir Friborg, Thormod Idsoe, Selcuk Sirin, and Brit Oppedal, 'Resilience and Acculturation among Unaccompanied Refugee Minors' (2018) 42 International Journal of Behavioral Development 52; Johanna Unterhitzenberger, Rima Eberle-Sejari, Miriam Rassenhofer, Thorsten Sukale, Rita Rosner, and Lutz Goldbeck, 'Trauma-Focused Cognitive Behavioral Therapy With Unaccompanied Refugee Minors: A Case Series’ (2015) 15 BMC Psychiatry 1.

${ }^{22}$ Keles (n21).
} 
'HSA') and the 2008 Trafficking Victims Protection Reauthorization Act (the 'TVPRA') both of which affirmed the authority of the ORR over the care and placement of UAC. ${ }^{23}$ The HSA abolished the former INS and established the Department of Homeland Security ('DHS'). The law also transferred the care of UAC from the former INS to the ORR. ${ }^{24}$ Under the HSA, a UAC is defined as an individual who: (1) has no lawful immigration status in the United States; (2) is under the age of eighteen; and, (3) must have either (a) 'no parent or legal guardian in the United States'; or (b) 'no parent or legal guardian in the United States ... available to provide care and physical custody'. ${ }^{25}$ The HSA required the ORR to ensure that 'the best interests of the child' are considered in decisions and actions concerning his or her care and custody. ${ }^{26}$ The HSA has a 'savings clause' that recognizes as effective and valid all administrative actions (e.g., orders, agreements, grants, contracts, certificates, licenses, registrations, and privileges) entered into by the INS until 'amended, modified, superseded, terminated, set aside, or revoked' in accordance with law. ${ }^{27}$

In 2008, Congress adopted the Trafficking Victims Protection Reauthorization Act (the 'TVPRA') which contained provisions relating to a UAC. Under the TVPRA, the HHS Secretary is responsible for the care, custody, and detention of a UAC. ${ }^{28}$ Other federal agencies holding a UAC were required to transfer custody to the ORR within 72 hours after determining that the minor is a UAC. ${ }^{29}$ Upon transfer to ORR custody, the ORR is required to promptly place the UAC in the 'least restrictive setting that is in the best interest of the child' ${ }^{30}$ The TVPRA, like the Flores Settlement, provides that if release is not possible, the UAC may be placed in a

\footnotetext{
${ }^{23}$ Tabbaa v. Chertoff 509 F.3d 89 (2nd Cir. 2007).

${ }^{24} 6$ U.S.C. $\S 279$ (a), 2002

${ }^{25}$ D.B. (n10) 732-733.

${ }^{26}$ Flores (n16) 870.

${ }^{27}$ ibid.

${ }^{28}$ D.B. $(\mathrm{n} 10)$.

${ }^{29}$ D.B. (n10); Flores (n16).

${ }^{30}$ ibid.
} 
specialized juvenile program or facility if the ORR determines that he or she 'poses a danger to self or others' or committed a criminal offense. ${ }^{31}$ The ORR was also required under the law to conduct monthly reviews of any placement of a UAC in a secure facility.

Under current ORR policies, field specialists initially determine whether to detain or release unaccompanied minors ('ORR Policies'). ${ }^{32}$ Before placing the UAC with a potential custodian, the ORR must: (1) ascertain whether the proposed custodian can provide for the minor's physical and mental well-being; and, (2) determine the necessity of a home study. ${ }^{33} \mathrm{~A}$ home study is mandatory when the proposed custodian 'clearly presents a risk of abuse, maltreatment, exploitation, or trafficking to the child'. ${ }^{4}$ The parent or legal guardian (but not any other sponsor) has 30 days to appeal the adverse decision to the Assistant Secretary for Children and Families. Under ORR Policies, the parent or guardian does not have the right to be represented by counsel at the placement hearing. ${ }^{35}$ The UAC can appeal a detention decision only if the sole reason for denial of release is that the UAC poses a danger to himself or to others. $^{36}$

\section{Method}

The WESTLAW database contains electronic copies of all published and unpublished court decisions. A keyword search was used to gather cases on unaccompanied alien children decided by all federal courts in the United States. The advanced search parameters required that the terms 'unaccompanied alien child' appeared in the main body of the case $(N=112)$. The authors

\footnotetext{
${ }^{31}$ ibid.

${ }^{32}$ Office of Refugee Resettlement, 'ORR Guide: Children Entering the United States Unaccompanied' (January 30 , 2015) <https://www.acf.hhs.gov/orr/resource/children-entering-the-united-states-unaccompanied $>$ accessed 1 February 2018.

${ }^{33}$ D.B. (n10).

${ }^{34}$ ibid. 734.

${ }^{35}$ Flores (n16) 872.

${ }^{36}$ ibid.
} 
then read each case individually and determined that not all cases were relevant to the article, either because the case did not involve unaccompanied alien children or did not contain sufficient facts to enable full analysis. Also, some of the cases were repeated because of the appeal process through the federal courts. The authors conducted an inductive doctrinal analysis to synthesize thirty-six (36) federal court decisions on the legal rights of an unaccompanied alien child under current U.S. laws. ${ }^{37}$

\section{Case Analysis}

\subsection{Issues concerning release or detention}

\subsubsection{Right to be released to a private custodian}

In Reno v. Flores, the U. S. Supreme Court considered whether a detained UAC who does not have any available parent, close relative, or legal guardian has the right to be released to the custody of any other 'willing-and-able private custodian' instead of being confined to a 'government-operated or government-selected child-care institution'. ${ }^{38}$ The Court examined whether a UAC has a fundamental constitutional right "not to be placed in a decent and humane custodial institution' if there is a responsible adult willing to accept 'temporary legal custody' but not willing to be the child's legal guardian ${ }^{39}$ The Court held that the INS regulations permitting release of a UAC only to his or her parents, close relatives, or legal guardians did not 'facially violate substantive due process'. ${ }^{40}$ As long as the government's intent is not punitive and custodial conditions are 'decent and humane', governmental custody of a juvenile who does not have any available parent, close relative, or legal guardian does not violate the Constitution. ${ }^{41}$

\footnotetext{
${ }^{37}$ Claire Nolasco, Michael S. Vaughn, and Rolando del Carmen, 'Toward a new methodology for legal research in criminal justice' (2010) 21 Journal of Criminal Justice Education' 1-23.

${ }^{38}$ Reno (n11) 302 .

${ }^{39}$ ibid. 303.

${ }^{40}$ ibid. 302.

${ }^{41}$ ibid. 303.
} 
The custody is rationally related to the government's interest in 'preserving and promoting the welfare of the child'. ${ }^{42}$

The Court acknowledged the authority of Congress to detain aliens suspected of entering the country illegally pending their deportation hearings. ${ }^{43}$ The INS regulations are rationally related to a legitimate governmental purpose, namely, concern for the juvenile's welfare who cannot be released to 'just any adult' and the State's lack of expertise and resources to conduct home studies for placement of every UAC. ${ }^{44}$ When the UAC's parent, close relative, or stateappointed guardian is not available, INS retains legal custody by placing the UAC in a 'government-supervised and state-licensed shelter-care facility'. ${ }^{45}$ The Court concluded that the INS can justify its policy of retaining custody because its regulations do not involve a deprivation of a fundamental right. The INS cannot be compelled to grant custody to strangers if that option requires substantial administrative effort and costs that it is unwilling to expend. Finally, the Court noted that INS custody of a UAC is not indefinite but is inherently limited to the duration of the deportation hearing. ${ }^{46}$ There was 'no evidence' that alien juveniles are held for 'undue periods' and that '(i)t is expected that alien juveniles will remain in INS custody an average of only 30 days'. ${ }^{47}$

\subsubsection{Right to due process in custody and placement decisions}

The Fourth Circuit considered the nature and extent of a UAC's due process rights in placement decisions in two related cases of D.B. v. Cardall $^{48}$ and Beltran v. Cardall. ${ }^{49}$ In D.B. v. Cardall, the issue was whether the ORR had continued authority to detain a UAC when deportation

\footnotetext{
${ }^{42}$ Reno (n11) 303; Santosky v. Kramer 455 U.S. 745, 766 (1982).

${ }^{43}$ Carlson v. Landon 342 U.S. 524, 538 (1952).

${ }^{44}$ Reno (n11) 310 .

${ }^{45}$ ibid. 311.

${ }^{46}$ ibid. 314.

${ }^{47}$ ibid.

${ }^{48}$ D.B. (n10).

${ }^{49}$ Beltran v. Cardall 222 F.Supp.3d 476 (E.D. Virginia 2016).
} 
proceedings are terminated. The case involved a Guatemalan citizen who illegally entered the United States with her four children, including R.M.B. who was then six years old. When the mother became a lawful permanent resident under the Violence Against Women Act (the 'VAWA'), the U.S. Citizenship and Immigration Services (the 'USCIS') granted deferred action to R.M.B. as a derivative beneficiary of his mother's VAWA petition. While attempting to smuggle undocumented immigrants near the Mexican-McAllen, Texas border, R.M.B. was arrested by Border Patrol agents and transferred to ORR custody, pending removal proceedings against him. The mother submitted a family reunification request to the ORR, asking for R.M.B.'s release to her custody. The ORR denied the request based on a home study recommending against release due to R.M.B.'s criminal history and high risk of recidivism. ${ }^{50}$ The immigration judge terminated the removal proceedings against R.M.B. because he had already been granted deferred action. ${ }^{51}$

The Fourth Circuit held that R.M.B. is a UAC based on the ORR's assessment that his mother was incapable of providing for his physical and mental well-being. ${ }^{52}$ The authority of ORR to detain R.M.B. did not cease upon termination of removal proceedings against him because ORR was specifically required by law to determine whether a proposed custodian can provide for the UAC's physical and mental well-being (the 'suitable custodian requirement'). ${ }^{53}$ The Fourth Circuit held that the suitable custodian requirement is an exception to the general rule that an alien cannot be detained upon termination of immigration proceedings against him. ${ }^{54}$

According to the Fourth Circuit, the case involved 'perhaps the oldest of the fundamental liberty interests', specifically, the fundamental right of parents to provide 'care, custody, and

\footnotetext{
${ }^{50}$ D.B. (n10).

${ }^{51}$ ibid.

${ }^{52}$ ibid.

${ }^{53}$ ibid.

${ }^{54}$ ibid.
} 
control of their children, 55 and the rights of children to be 'raised and nurtured' by their parents. ${ }^{56}$ The Fourth Circuit remanded the case, requiring the district court to apply the U.S. Supreme Court's procedural due process standard in Mathews v. Eldridge ${ }^{57}$ (the 'Mathews test'). ${ }^{58}$ The Mathews test requires an analysis of: (1) the private interest that will be affected by the official action; (2) the 'risk of an erroneous deprivation of such interest' through the procedures used, and the 'probable value, if any, of additional or substitute procedural safeguards;' and, (3) the Government's interest and the 'fiscal and administrative burdens' that 'additional or substitute procedural requirement would entail'. 59

On remand, the district court in Beltran v. Cardall, concluded that the ORR's family reunification procedures did not provide R.M.B and petitioner due process of law based on the Mathews test. ${ }^{60}$ The district ordered R.M.B.'s release to care and custody of his mother and held that: (1) mother and child had a fundamental liberty interest in family integrity, which was protected by procedural due process; (2) the risk of erroneous deprivation of petitioner's fundamental liberty interests required ORR to ensure due process in its procedures for family reunification; and (3) the governmental interest involved was not sufficient to rule that ORR was not required to implement additional measures to guaranty procedural due process.

The district court stated that the petitioner's right to the care and custody of her son and R.M.B.'s reciprocal right to his mother's care is 'deserving of the greatest solicitude'. ${ }^{61}$ The 'private fundamental liberty interest' in retaining custody of one's children is an 'essential, basic

\footnotetext{
${ }^{55}$ Beltran (n49) 481; D.B. (n10) 740; Troxel v. Granville 530 U.S. 57, 65 (2000).

${ }^{56}$ Beltran (n49) 482; Berman v. Young 291 F.3d 976, 983 (7th Cir. 2002); D.B. (n10) 740.

${ }^{57}$ Mathews v. Eldridge 424 U.S. 319 (1976).

${ }^{58}$ Bauer v. Lynch 812 F.3d 340 (4th Cir. 2016); Ciambriello v. Cty. of Nassau 292 F.3d 307 (2nd Cir. 2002).

${ }^{59}$ Mathews (n57).

${ }^{60}$ Beltran (n49).

${ }^{61}$ Beltran (n49) 482; Jordan by Jordan v. Jackson 15 F.3d 333, 345-346 (4th Cir. 1994).
} 
civil right of man...far more precious than property rights'. ${ }^{62}$ Also, '[t]he forced separation of parent from child, even for a short time, represents a serious impingement on' the right to family integrity. ${ }^{63}$ Here, petitioner and R.M.B. were separated for nearly three years. While in the custody of the ORR, R.M.B. was held in juvenile detention facilities, the most restrictive placement. As a result, the mother has been deprived of 'meaningful contact with her son'. 64

The district court then examined the adequacy of ORR procedures for placement of UAC with suitable custodians. ${ }^{65}$ Here, the ORR ordered a home study upon submission of the family reunification form by the mother. The home study recommended against releasing R.M.B. to petitioner's care because of R.M.B.'s behavioral problems instead of the mother's parental fitness. ${ }^{66}$ A month after the home study, petitioner received a short letter stating that her request was denied because R.M.B. required an environment with a 'high level of supervision and structure'. ${ }^{67}$ The district court concluded that the ORR process was deficient because the proceedings were unilateral and petitioner was not informed of the evidence or the facts relied upon. Under Supreme Court and Fourth Circuit precedent, the state has the 'burden to initiate proceedings to justify its action' once it withholds a child from a parent's care. ${ }^{68}$ Adversarial hearings are required when 'subjective judgments' that are 'peculiarly susceptible to error' are disputed. ${ }^{69}$ The determination of whether a proposed custodian can provide for a UAC's physical and mental well-being is a 'complex and subjective inquiry' ${ }^{70}$ The court concluded that ORR deprived petitioner of a meaningful opportunity to present her case because it made the

\footnotetext{
${ }^{62}$ Stanley v. Illinois 405 U.S. 645 (1972); Weller v. Dep't of Soc. Servs. for City of Baltimore 901 F.2d 387 (4th Cir. 1990).

${ }^{63}$ Jordan (n61) 345.

${ }^{64}$ Beltran (n49) 482.

${ }^{65}$ ibid.

${ }^{66}$ Beltran (n49) 484.

${ }^{67}$ Beltran (n49) 485.

${ }^{68}$ Beltran (n49) 486; Duchesne v. Sugarman 566 F.2d 817 (2nd Cir. 1977); Stanley (n62); Weller (n62).

${ }^{69}$ Beltran (n49).

${ }^{70}$ ibid.
} 
subjective judgment without 'any form of hearing'.71 All the procedures of the ORR for placement consisted of 'internal evaluation and unilateral investigation'. ${ }^{72}$ The ORR's deficient procedures 'created a significant risk' that petitioner and R.M.B. would be 'erroneously deprived of their right to family integrity'. ${ }^{73}$

In Santos v. Smith, the United States District Court for the Western District of Virginia also applied the Mathews test in determining whether a UAC was deprived of due process when the ORR denied his mother's request for relase to her custody. ${ }^{74}$ In this case, Santos fled Honduras when O.G.L.S. was five years old to escape physical abuse from her husband. When he was 14 years old, O.G.L.S. fled Honduras and entered the United States to be reunited with his mother. He was apprehended, determined to be a UAC, and transferred to ORR custody. After O.G.L.S. disclosed his participation in criminal gang activities, ORR placed him at the Shenandoah Valley Juvenile Center ('SVJC'), a secure facility in Staunton, Virginia. The mother filed a petition with ORR asking to be reunified with her son. ORR conducted a home study which recommended reunification, specifically noting that 'Ms. Santos [and her husband] will be positive influences on the minor, and that he should be released to their care' ${ }^{75}$ The ORR issued a decision more than 14 months after the home study was completed and denied the application for family reunification. The mother filed a petition for writ of habeas corpus alleging that ORR violated her due process rights and sought O.G.L.S.'s immediate release to her custody.

The district court held that the detention of O.G.L.S. for more than 29 months violated procedural due process and ordered his immediate release to the custody of Santos. The district court stated that due process consists of 'notice and the opportunity to be heard' at a

\footnotetext{
${ }^{71}$ ibid.

${ }^{72}$ ibid.

${ }^{73}$ ibid.

${ }^{74}$ Santos v. Smith 260 F.Supp.3d 598 (W. D. Virginia 2017).

${ }^{75}$ ibid. 602.
} 
'meaningful' time and manner. ${ }^{76}$ Applying the first factor in the Mathews test, the court stated that the private interests impacted both the fundamental right of petitioners to family reunification and O.G.L.S.'s right to liberty. ${ }^{77}$ The court opined that 'a more fulsome process' would 'considerably lessen the risk of an erroneous deprivation' of the fundamental interest in family reunification. ${ }^{78}$

The court identified key deficiencies in the ORR process. First, the ORR did not adequately explain the reasons for its decision. Second, the ORR process 'improperly placed the burden of initiation and persuasion on the petitioner' ${ }^{79}$ The burden should be on ORR to show the necessity of continued custody of the UAC rather than on the parent to show the propriety of release. ${ }^{80}$ Third, there were 'very lengthy delays' in the ORR's processing of the petition for reunification. $^{81}$ The 'egregious' 17 -months delay before the ORR decided on the initial application for reunification violated due process. ${ }^{82}$ The court also noted that because of this delay, O.G.L.S.'s psychological condition worsened while in placement. Fourth, no hearing was conducted before an impartial judge.

\subsubsection{Right to the bond hearing of the Flores settlement}

In Flores v. Sessions, the Ninth Circuit considered whether subsequent statutes revoked the Flores Settlement, including paragraph 24A which grants every minor in deportation proceedings the right to a bond redetermination hearing before an immigration judge 'unless the minor indicates on the Notice of Custody Determination form that he or she refuses such a

\footnotetext{
${ }^{76}$ Armstrong v. Manzo 380 U.S. 545 (1965); Santos (n74) 611.

${ }^{77}$ Santos (n74) 611.

${ }^{78}$ ibid.

${ }^{79}$ Santos (n74) 613.

${ }^{80}$ Addington v. Texas 441 U.S. 418 (1979); Foucha v. Louisiana 504 U.S. 71 (1992); Santos (n74); Thach v. Arlington Cty. Dep't of Human Servs. 754 S.E.2d 922 (2014); United States v. Salerno 481 U.S. 739 (1987).

${ }^{81}$ Santos (n74) 613.

${ }^{82}$ Santos (n74) 614.
} 
hearing'. ${ }^{83}$ Plaintiffs alleged that ORR currently detains UAC 'for months, and even years' without providing them any opportunity to challenge the basis for their detention before an independent immigration judge. ${ }^{84}$ The Ninth Circuit invoked the basic rules of statutory construction, noting that the plain texts of the HSA and TVPRA did not explicitly terminate the Flores Settlement's bond-hearing requirement. The bond hearing under Paragraph 24A of the Flores Settlement is a fundamental protection for a UAC that does not automatically result in the setting of bail or release of the UAC. ${ }^{85}$ Even if the immigration judge decides that detention by the ORR is improper, the ORR must still identify a 'safe and secure placement' for the release of the minor. ${ }^{86}$

Compared to ORR policies, the bond hearing requirement under the Flores Settlement provides 'significant practical benefits to unaccompanied minors'. ${ }^{87}$ ORR policies do not guarantee a UAC the right to present evidence, the right to legal counsel, and does not 'identify any standard of proof' including evidentiary requirements. ${ }^{88}$ In contrast, bond hearings allow minors to be represented by legal counsel, provide oral statements, present supporting evidence, and is appealable to the Board of Immigration Appeals. The Flores Settlement grants minors an automatic bond hearing 'unless affirmatively waived' while the ORR review process 'must be affirmatively invoked'. ${ }^{89}$ The Ninth Circuit pointed out that plaintiff's experiences are a 'strong indication' that ORR's current policies are 'inadequate' and that bond hearings 'will provide a meaningful benefit to unaccompanied minors'. 90 The Ninth Circuit concluded that the Flores Settlement is binding on the government, 'regardless of which agency may now be charged with

\footnotetext{
${ }^{83}$ Flores (n16) 869.

${ }^{84}$ ibid. 872.

${ }^{85}$ Flores (n16).

${ }^{86}$ Flores (n16) 867.

${ }^{87}$ Flores (n16) 877.

${ }^{88}$ Flores (n16) 878.

${ }^{89}$ Flores (n16) 879.

${ }^{90}$ ibid.
} 
caring for unaccompanied minors. ${ }^{91}$

\subsection{Issues concerning voluntary departure}

\subsubsection{Rights before signing a voluntary departure consent form}

Voluntary departure is a form of relief for a qualified alien who is apprehended by immigration officials. ${ }^{92}$ INS policies allow an alien to consent to summary removal from the United States at his or her expense upon signing a voluntary departure form (form I-274), waiving the right to a deportation hearing and all other forms of relief. INS policies on voluntary departure for UAC vary 'according to the age, residence, and place of apprehension of the child' ${ }^{93}$ For UAC aged fourteen to sixteen, the INS gathers information on the UAC through form I-213, notifies the UAC of the remedy of voluntary departure, and asks the child to indicate whether he or she opts for voluntary departure or a deportation hearing. For UAC who are permanent residents of Mexico and Canada and are arrested near the Mexican or Canadian borders, the INS temporarily detains the UAC until a foreign consulate official arrives. The UAC is then returned to his or her home country upon requesting voluntary departure.

Plaintiff UAC aged 12 to 16 alleged that, upon apprehension, INS asked them to sign a voluntary departure consent form without advising them of their rights 'in a meaningful manner' ${ }^{94}$ They filed a class action on the ground that the INS violated their due process rights because they were forced to 'unknowingly and involuntarily' select voluntary departure and waive their rights to a deportation hearing or other forms of relief. ${ }^{95}$ The district court ruled in favor of plaintiffs and granted a permanent injuction.

The District Court for the Central District of California applied the three-part test of

\footnotetext{
${ }^{91}$ ibid.

${ }_{92}^{92}$ Perez-Funez v. District Director I.N.S. 619 F.Supp. 656 (C. D. California 1985).

${ }^{93}$ ibid. 658.

${ }^{94}$ ibid. 657.

${ }^{95}$ ibid. 656-657.
} 
Mathews v. Eldridge to resolve the procedural due process issue: (1) the private interest affected; (2) the 'risk of erroneous deprivations of rights' under the INS procedures and the 'probable value, if any, of additional or substitute procedural safeguards;' and, (3) the government's interest involved and the burdens imposed by 'supplemental or substitute procedures. ${ }^{96}$ The court asserted that a UAC possesses 'substantial constitutional and statutory rights' despite illegally entering the country. ${ }^{97}$ Under 8 U.S.C. $§ 1252$ (b), an alien has the the rights to an evidentiary hearing, notice, counsel (at no expense to the government), present evidence, cross-examine witnesses, and to a 'decision based upon substantial evidence'. ${ }^{98}$ A UAC has a right to a deportation hearing, which is waived upon signing the voluntary departure form. When the UAC waives the right to a deportation hearing, he or she "effectively waives the right to various forms of relief from deportation', including: (1) adjustment of status; ${ }^{99}$ (2) suspension of deportation; ${ }^{100}$ (3) political asylum ${ }^{101}$ or withholding of deportation; ${ }^{102}$ and (4) deferred action status. ${ }^{103}$ Plaintiffs 'do not possess rights equivalent to those of criminal defendants' because 'deportation proceedings are civil in nature'. ${ }^{104}$ In deportation proceedings, a UAC cannot invoke the exclusionary rule, ${ }^{105}$ Miranda warnings, ${ }^{106}$ and the right to appointed counsel. ${ }^{107}$

The court asserted that 'the risk of erroneous deprivation is great' especially for UAC who are 'not arrested near the border' or are not permanent residents of Mexico or Canada. ${ }^{108}$ The INS procedures on voluntary departure are 'inherently coercive' and did not result in

\footnotetext{
${ }^{96}$ Mathews (n57) 335; Perez-Funez (n92) 659.

${ }^{97}$ Mathews v. Diaz 426 U.S. 67, 77 (1976); Perez-Funez (n92) 659.

${ }^{98}$ Perez-Funez (n92) 660.

${ }^{99} 8$ U.S.C. $\S 1254$.

${ }^{100} 8$ U.S.C. $\$ 1254$.

${ }^{101} 8$ U.S.C. $\S 1158$.

${ }^{102} 8$ U.S.C. $\S 1253(\mathrm{~h})(1)$

${ }^{103}$ Perez-Funez (n92) 660.

${ }^{104}$ INS v. Lopez-Mendoza 468 U.S. 103 (1984); Perez-Funez (n92) 659.

${ }^{105}$ Perez-Funez (n92).

${ }^{106}$ Trias-Hernandez v. INS 528 F.2d 366 (9th Cir.1975).

${ }^{107}$ Martin-Mendoza v. INS 499 F.2d 918 (9th Cir. 1974).

${ }^{108}$ Perez-Funez (n92) 663.
} 
'effective waivers' because the UAC did not understand their rights when they signed the voluntary departure form. ${ }^{109} \mathrm{~A}$ waiver is 'an intentional relinquishment or abandonment of a known right or privilege'. ${ }^{110}$ A valid waiver of any right requires that the person 'fully understands the right' and 'voluntarily intends to relinquish it'. ${ }^{111}$ Here, the plaintiffs did not understand the forms and their contents. Their ages, the 'stressful situation', the 'new and complex' environment and laws, and the 'foreign and authoritarian' interrogators made the entire process 'inherently coercive'. ${ }^{112}$

The court then considered the 'probable value of additional or substitute safeguards in minimizing the aforementioned risk of deprivation'. ${ }^{113}$ The court surmised that 'access to telephones prior to presentation of the voluntary departure form' is the 'only way to ensure a knowing waiver of rights'. ${ }^{114}$ Although legal counsel is the 'best insurance against a deprivation of rights', case law forecloses the right of UAC to appointed counsel at government expense. ${ }^{115}$ Other alternatives to legal counsel include providing the UAC with the oportunity to contact a parent, close adult relative, or adult friend. ${ }^{116}$ The district court held that these additional safeguards are not 'unduly burdensome' on the government and issued a permanent injunction with the following conditions: (1) INS shall provide all UAC with an updated free legal services list and a simplified rights advisal approved by the court; (2) before presenting the voluntary departure form, INS shall provide all UAC apprehended near the U.S. borders and who reside permanently in Mexico or Canada 'the opportunity to make a telephone call to a parent, close relative, or friend, or to an organization... on the free legal services list;' (3) before presenting the

\footnotetext{
${ }^{109}$ ibid. 663).

${ }^{110}$ Johnson v. Zerbs 304 U.S. 458 (1938).

${ }_{111}^{111}$ Edwards v. Arizona 451 U.S. 477 (1981); Perez-Funez (n92).

${ }^{112}$ Perez-Funez (n92) 662.

${ }^{113}$ Mathews (n57) 335.

${ }^{114}$ Perez-Funez (n92) 664.

${ }^{115}$ Martin-Mendoza v. INS (n107) 922; Perez-Funez (n92) 665.

${ }^{116}$ Eddings v. Oklahoma 455 U.S. 104, 115 (1982).
} 
voluntary departure form to all other UAC not apprehended at a U.S. border, INS shall provide and ensure that they have access to telephones and actually communicated with a 'parent, close adult relative, friend, or with an organization found on the free legal services list;' (4) INS shall obtain a 'signed acknowledgment' on a 'separate copy of the simplified rights advisal' showing that the INS provided the UAC with all required notices and information; and, (5) the district director shall update and maintain the free legal services list. ${ }^{117}$

\subsection{Issues concerning asylum applications}

\subsubsection{Right of third parties to custody of the unaccompanied alien child}

An asylum application cannot be filed by a six-year-old unaccompanied minor or his relative who does not have legal custody, if the parent of the UAC opposes the application. ${ }^{118}$ Third parties who are not related to the UAC cannot gain custody of the minor or be appointed as custodians by a state juvenile court without the consent of the Secretary of the DHS. ${ }^{119}$

\subsubsection{Minority age at the time of the application for asylum}

The TVPRA exempts UAC from the one-year time limitation for filing an asylum application. ${ }^{120}$ To qualify for the TVPRA's jurisdictional provision, the applicants must qualify as UAC at the time they file an asylum application even if he or she turned eighteen years old thereafter. ${ }^{121}$ Minors who do not qualify as UAC upon filing of the asylum application were 'not statutorily exempted' from the one-year time limit. ${ }^{122}$

\subsubsection{Right to request consent for a state juvenile court's jurisdiction}

The DHS and not the ORR has authority to grant a UAC's request for consent to a state juvenile

\footnotetext{
${ }^{117}$ Perez-Funez (n92) 670.

${ }^{118}$ Gonzalez v. Reno 212 F.3d 1338 (11th Cir. 2000).

${ }^{119}$ United States ex rel. K.E.R.G. v. Burwell 2014 WL 12638877 (E.D. Pennsylvania 2014).

${ }^{120}$ Flores-Lobo v. Holder 562 Fed.Appx. 262 (5th Cir. 2014).

${ }^{121}$ United States Customs and Immigration Services, 'Memorandum 2' (25 March 2009) $<$ http://www.ilw.com/immigrationdaily/news/2009,0327-unaccompanied.pdf $>$ accessed 2 February 2018; Xin Yu He v. Lynch 610 Fed.Appx. 655 (9th Cir. 2015).

${ }^{122}$ Flores-Lobo (n120) 263.
} 
court's jurisdiction. ${ }^{123}$ The case of F.L. v. Thompson involved a seventeen-year old Tanzanian UAC who was transferred to the custody of the INS and placed with a Michigan foster family. ${ }^{124}$ He planned to request a Michigan juvenile court for a declaration of dependency that would allow him to apply for a special immigrant juvenile ('SIJ') visa to prevent his deportation. Since he was in government custody, the law required him to first obtain the U.S. Attorney General's consent to the jurisdiction of the Michigan juvenile court before filing the petition for a declaration of dependency ('jurisdictional consent'). ${ }^{125}$ Plaintiff requested the ORR to grant jurisdictional consent. ORR declined, instead transferring his request to DHS. The District Court for the District of Columbia held that under the HSA, the DHS and not the ORR has authority to grant or deny the UAC's request.

The district court traced the background of the SIJ immigration status to the Immigration and Nationality Act ('INA') (1997). Under Section 1101(a)(27)(J) of the INA (1997), acquisition of a declaration of dependency from a state court is a prerequisite to applying for an SIJ visa, available to certain unmarried aliens under the age of twenty-one. The law defines SIJs as unaccompanied minors determined by state courts to be eligible for 'long-term foster care due to abuse, neglect or abandonment suffered in their home countries' when family unification is not possible and return to their home country is not in their best interest. ${ }^{126}$ The statute allowed a state court to assume jurisdiction over a juvenile immigrant under INS custody. ${ }^{127}$ In 1997 , Congress amended the statute to require the Attorney General to consent to the state court's exercise of jurisdiction. $^{128}$

\footnotetext{
${ }^{123}$ F.L. v. Thompson, 293 F.Supp.2d 86 (D.C. Cir. 2003).

${ }^{124}$ F.L. (n123).

${ }^{125}$ Immigration and Nationality Act (INA), H.R. 2580; Pub.L. 89-236, 79 Stat. 911 (1997).

${ }^{126}$ F.L. (n123) 89.

${ }^{127}$ F.L. (n123); M.B. v. Quarantillo 301 F.3d 109 (3d Cir. 2002).

${ }^{128}$ F.L. (n123) 90.
} 
The HSA (2002) abolished the INS and divided the responsibilities for UAC between the DHS and ORR - specific juvenile care responsibilities were transferred to the ORR while authority to adjudicate immigration benefits (e.g., SIJ visas) were vested in the DHS. ${ }^{129}$ Jurisdictional consent is the 'first step of the three-step process' that a minor must follow to obtain an SIJ visa. ${ }^{130}$ Consent and SIJ status are also in the same section of the statute providing for 'other immigration benefits' - a responsibility of the DHS. ${ }^{131}$ The court then also analyzed the legislative purpose for granting the consent authority to the Attorney General. The legislative history of the 1997 INA amendment indicates that the Attorney General's consent 'was imposed as a precondition to juvenile court jurisdiction' to ensure that SIJ applicants 'have a special need to remain in the United States' and 'do not use the process simply to gain an immigration benefit'. ${ }^{132}$ Since the DHS decides whether to grant or deny SIJ status, it is 'logical to have DHS exercise control over the preliminary consent stage'. ${ }^{133}$

The Third Circuit reiterated that the INS (now the DHS) has broad discretion to allow or deny consent to a state court's jurisdiction in a dependency hearing to grant SIJ status. ${ }^{134}$ In Yeboah v. U.S. Dept. of Justice, the INS denied a 10-year old Ghanaian UAC request for consent to a state court's jurisdiction to declare him a dependent for purposes of obtaining SIJ status. ${ }^{135}$ The INS ruled that the minor: (1) was not entitled to SIJ status because he was not abused, neglected, or abandoned; and, (2) was seeking SIJ status for the 'improper purpose of obtaining permanent resident status' - he was placed on the plane by his father 'as part of an unworkable

\footnotetext{
${ }^{129}$ Homeland Security Act Pub. L. No. 107-296, 116 Stat. 2135 (2002).

${ }^{130}$ F.L. (n123) 92.

${ }^{131}$ ibid.

${ }^{132}$ ibid. 96.

${ }^{133}$ ibid. 97.

${ }^{134}$ Yeboah v. U.S. Dept. of Justice 2003; M.B. (n127).

${ }^{135}$ Yeboah (n134).
} 


\footnotetext{
${ }^{136}$ Yeboah (n134) 219-222.

${ }^{137}$ Jay v. Boyd 351 U.S. 345, 351-352 (1956); Yeboah (n134) 224.

${ }^{138}$ J.E.F.M. v. Lynch 837 F.3d 1026 (9th Cir. 2016).

${ }^{139}$ ibid. 1026.

${ }^{140}$ ibid. 1028.

${ }^{141}$ ibid.

${ }^{142}$ ibid.

${ }^{143}$ Alvarado v. Holder 759 F.3d 1121 (9th Cir. 2014); Barron v. Ashcroft 358 F.3d 674 (9th Cir. 2004); J.E.F.M. (n138); Ram v. Mukasey 529 F.3d 1238 (9th Cir. 2008); Sola v. Holder 720 F.3d 1134 (9th Cir. 2013); ZepedaMelendez v. INS 741 F.2d 285 (9th Cir. 1984).
} 
'final removal order' of an immigration judge or the Board of Immigration Appeals. ${ }^{144}$

The Ninth Circuit continued that immigration judges 'have an obligation to ask whether a petitioner wants counsel' ${ }^{145}$ Although immigration judges are not required to 'undertake Herculean efforts' to grant petitioners the right to counsel, 'at a minimum' they must determine: (1) whether the petitioner wants counsel; (2) a reasonable period for obtaining counsel; and, (3) assess the voluntariness of any waiver. ${ }^{146}$ The Ninth Circuit stated that the failure of an immigration judge to inquire whether the petitioner wanted or knowingly waived counsel 'is grounds for reversal'. ${ }^{147}$

In Nehimaya-Guerra v. Gonzales, the Ninth Circuit held that the minor was denied due process during the removal proceeding: (1) when the immigration judge conducted a group hearing of fifteen individuals and did not inquire as to plaintiff's status as a minor; and, (2) when plaintiff admitted removability because she was not represented by an adult or legal counsel. ${ }^{148}$ The Department of Justice ('DOJ') guidelines require 'special treatment' of a UAC and prohibit immigration judges from accepting 'an admission of removability' from UAC who are not accompanied by an 'attorney or legal representative, a near relative, legal guardian, or friend' ${ }^{149}$

\subsubsection{Right to a bond rehearing upon rearrest on allegations of gang membership}

In Saravia v. Sessions, the District Court for the Northern District of California issued a preliminary injunction requiring the government to grant a hearing before an immigration judge to any UAC previously placed with a sponsor but rearrested on allegations of gang activity. ${ }^{150}$ In this case, ICE agents implementing 'Operation Matador' targeted undocumented immigrants in

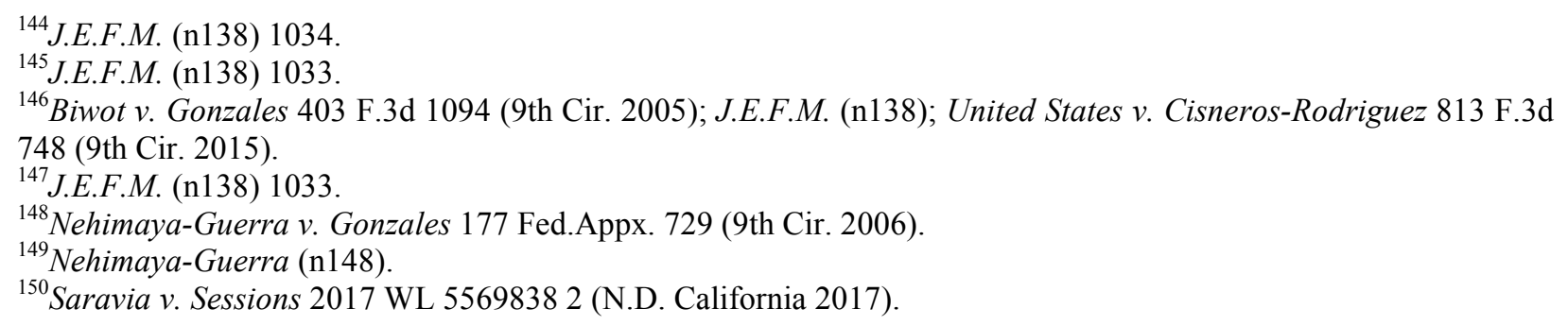


two New York counties (Suffolk and Nassau) allegedly connected to criminal gangs. ${ }^{151}$ ICE agents rearrested plaintiffs due to allegations of gang involvement from local law enforcement. Plaintiffs were previously arrested as unaccompanied minors, transferred to ORR custody, and released to either parents or sponsors because of the ORR's prior determination that they were not dangerous. Upon rearrest by ICE on suspicion of gang affiliation, they were placed in juvenile detention facilities, the most restrictive secure facility level. The district court required the government '(g)oing forward, at least while this lawsuit is pending' to provide the plaintiffs with notice of the basis for rearrest and an opportunity to rebut evidence in 'a hearing within seven days of arrest of any such minor'. ${ }^{152}$ Venue for the hearing must be 'in the jurisdiction where the minor has been arrested or where the minor lives' ${ }^{153}$

The court noted that federal agents have been arresting noncitizens, including UAC previously placed with sponsors, 'based on allegations of gang involvement'. ${ }^{154}$ Adult aliens may be released on bond or parole pending removal proceedings as long as the federal government determines that they do not pose a danger to the community or are not a flight risk. Once released on bond, the law prohibits federal agents from rearresting the alien 'merely because he is subject to removal proceedings'. ${ }^{155}$ The government must 'present evidence of materially changed circumstances' that the alien 'is in fact dangerous or has become a flight risk, or is now subject to a final order of removal'. ${ }^{156}$ The alien is entitled under federal laws and current DHS policies 'to a prompt hearing before an immigration judge' to dispute the notion that 'changed circumstances justify his rearrest'. ${ }^{157}$ The court commiserated that UAC do not receive the same

\footnotetext{
${ }^{151}$ ibid.

${ }^{152}$ ibid.

${ }^{153}$ ibid. 17.

${ }^{154}$ ibid. 1.

${ }^{155}$ ibid.

${ }^{156}$ ibid.

${ }^{157}$ ibid.
} 
protections as alien adults released on bond because they are not given a 'prompt hearing' to dispute that their detention is justified 'based on changed circumstances'. ${ }^{158}$ The government instead transferred the minors to high-security facilities for an indefinite period.

The court then applied the Mathews v. Eldridge standard to determine the due process requirements in the case. ${ }^{159}$ Here, the plaintiffs have a 'strong interest' under the Fifth Amendment due process clause 'in being free from unnecessary government interference with their liberty'. ${ }^{160}$ Since some of the plaintiff UAC were in the custody of their parents when they were rearrested and transferred to detention facilities, the government's actions triggered the 'long-recognized interest' of a parent in 'the companionship, care, custody and management of his or her children'. ${ }^{161}$ UAC previously placed by the ORR with a sponsor cannot be rearrested 'solely on the ground that he is subject to removal proceedings'. ${ }^{162}$ A lawful arrest must be based on evidence of changed circumstances, indicating that the UAC pose a danger to self or the community or present a flight risk. The UAC and their sponsors 'have the right to participate in a prompt hearing before an immigration judge' to contest the government's allegation of 'changed circumstances'. ${ }^{163}$ The court stated that the government violated the due process rights of the UAC by indefinitely detaining then in high-security facilities without providing them a hearing.

Without 'a prompt adversarial hearing', there is a 'serious risk' that minors previously placed by ORR with sponsors will be rearrested based on 'insufficiently substantial allegations of gang affiliation' and 'erroneously placed into ORR custody'. ${ }^{164}$ The Ninth Circuit recognized that the determination of active gang membership 'presents a considerable risk of error' due to

\footnotetext{
${ }^{158}$ ibid.

${ }^{159}$ Mathews (n57) 335.

${ }^{160}$ Saravia (n150) 15.

${ }^{161}$ Berman (n56) 983; D.B. (n10) 740; Lassiter v. Dep't of Soc. Servs. 452 U.S. 18 (1981); Saravia (n150) 15.

${ }^{162}$ Saravia (n150). 15.

${ }^{163}$ Saravia (n150) 1.

${ }^{164}$ Saravia (n150) 18.
} 
the 'informal structure of gangs, the often fleeting nature of gang membership, and the lack of objective criteria in making the assessment'. ${ }^{165}$ These additional protections do not 'impose any significant burden on the federal government' because: (1) there is already a similar process for adult noncitizens rearrested after release on bond; (2) the safeguards will enhance the government's capacity to act in the UAC's best interest by placing him or her 'in the least restrictive setting;' and, (3) these protections will reduce the risk that a UAC 'is erroneously removed from a sponsor's custody and placed into a taxpayer-funded juvenile detention facility'. 166

\subsection{Issues concerning detention in facilities}

\subsubsection{Legal standard for abuses experienced in facilities}

The Supreme Court in Farmer v. Brennan ${ }^{167}$ prescribed the legal standard of deliberate indifference to determine whether a government official's 'episodic act or omission' violated plaintiffs' Fifth Amendment due process right to protection from harm. ${ }^{168}$ A government official is liable if he or she: (1) had 'subjective knowledge of a substantial risk of harm' to the plaintiff ('subjective awareness'); and, (2) did not respond in an 'objectively reasonable' manner 'in light of clearly established law' ('objectively reasonable response'). ${ }^{169}$ To prove subjective awareness, defendant officials must have 'actual notice of an existing risk' or must have inferred the obvious risk based on facts known to him, including circumstantial evidence. ${ }^{170}$ Defendant officials who had subjective awareness may be found liable only if did not respond in an 'objectively

\footnotetext{
${ }^{165}$ Vasquez v. Rackauckas 734 F.3d 1025, 1046 (9th Cir. 2013).

${ }^{166}$ Saravia (n150) 19.

${ }^{167}$ Farmer v. Brennan 511 U.S. 825 (1994).

${ }^{168}$ E.A.F.F. v. Gonzalez 600 Fed.Appx. 205, 210 (5th Cir. 2015); Hare v. City of Corinth Miss. 74 F.3d 633, 647 (5th Cir.1996).

${ }^{169}$ E.A.F.F. (n168) 211; Farmer (n167) 884; Jacobs v. W. Feliciana Sheriff's Dep't. 228 F.3d 388 (5th Cir. 2000).

${ }^{170}$ Farmer (n167) 837.
} 
reasonable manner even if the harm ultimately was not averted'. ${ }^{171}$ The government may raise the defense of 'qualified immunity from monetary damages' against claims of deliberate indifference. ${ }^{172}$ The defense of qualified immunity requires a two-step analysis: (1) whether defendants violated a 'clearly established right' of the plainfiff; and, (2) whether defendants' conduct was 'objectively reasonable in light of clearly established law at the time of the incident'. ${ }^{173}$

The Fifth Circuit applied the deliberate indifference standard in E.A.F.F. v. Gonzalez, involving eleven unaccompanied Central American minors arrested by Texas Border Patrol agents and placed by the ORR in a Nixon, Texas detention facility pending immigration proceedings. ${ }^{174}$ They filed an action against defendant ORR officials in their individual capacities under Bivens v. Six Unknown Named Agents of Federal Bureau of Narcotics ${ }^{175}$ ('Bivens action'), claiming monetary damages for violation of their constitutional rights. ${ }^{176}$ They alleged that they were physically or sexually abused while detained in the Nixon facility.

The Fifth Circuit held that the plaintiffs failed to prove that defendants were deliberately indifferent to their Fifth Amendment due process rights to be protected from harm because defendants did not have 'subjective awareness of the risk' - they did not have 'actual knowledge' or the risk was not obvious. ${ }^{177}$ In Farmer v. Brennan, U.S. Supreme Court explained that a risk 'may be obvious' when inmate attacks were 'longstanding, pervasive, welldocumented, or expressly noted by prison officials in the past'. ${ }^{178}$ Here, there was no pattern of

\footnotetext{
${ }^{171}$ Farmer (n167) 884.

${ }^{172}$ Doe v. Robertson 751 F.3d 383, 387 (5th Cir. 2014); E.A.F.F. (n168) 209.

${ }^{173}$ E.A.F.F. (n168) 209; Hernandez ex rel. Hernandez v. Tex. Dep't of Protective \& Regulatory Servs. 380 F.3d 872, 879 (5th Cir. 2004).

${ }^{174}$ E.A.F.F. (n168).

${ }^{175}$ Bivens v. Six Unknown Named Agents of Federal Bureau of Narcotics 403 U.S. 388 (1971).

${ }^{176}$ Brown v. Nationsbank Corp. 188 F.3d 579 (5th Cir.1999).

${ }^{177}$ E.A.F.F. (n168) 205).

${ }^{178}$ Farmer (n167) 842.
} 
abuse that made the risk obvious to the defendant officials because there was 'only one confirmed case of sexual abuse and one confirmed case of physical abuse' which led to the suspension or termination of the perpetrators. ${ }^{179}$ The Fifth Circuit concluded that the government officials were entitled to qualified immunity because they responded reasonably to the perceived risk. Upon learning of the isolated incidents, defendants implemented policies to ensure more frequent monitoring of staff and preventing staff from entering bathrooms and bedrooms without an escort, reviewed staffing procedures, and scheduled additional staff training. ${ }^{180}$

\subsection{Other legal rights while in United States' territory}

\subsubsection{Right to terminate pregnancy}

A recent case involved the right of a UAC to terminate her pregnancy while in custody of the ORR. In Garza v. Hargan, plaintiff filed a petition for a temporary restraining order to prevent the government from interfering with her access to abortion counseling and right to abortion. ${ }^{181}$ The district court granted the injunction. On appeal, the District of Columbia Circuit Court 'en banc' denied the government's emergency motion for stay pending appeal and remanded to the district court for 'further proceedings to amend the effective dates of its injunction'. ${ }^{182}$ In a concurring opinion, Circuit Judge Millett noted that plaintiff, 'like other minors in the United States who satisfy state-approved procedures', is entitled under binding Supreme Court precedent to choose to terminate her pregnancy. ${ }^{183}$ The Due Process Clause of the Fifth Amendment 'fully protects' plaintiffs' right to decide whether to continue or terminate pregnancy. ${ }^{184}$ Her status as an unaccompanied alien child does not reduce or eliminate her

\footnotetext{
${ }^{179}$ E.A.F.F. (n168) 213.

${ }^{180}$ ibid. 215.

${ }^{181}$ Garza v. Hargan, 874 F.3d 735 (D.C. Cir. 2017).

182 ibid. 735.

183ibid. 737.

${ }^{184}$ ibid.
} 
constitutional right to an abortion in compliance with state law requirements. ${ }^{185}$

The government argued that the plaintiff 'has the burden of extracting herself' from the ORR's custody if she 'wants to exercise the right to an abortion'. ${ }^{186}$ According to the government, a UAC may obtain an abortion only if: (1) she finds a sponsor willing to and legally qualified to obtain custody of her; or (2) she voluntarily returns to her home country. The concurring opinion countered that this position is untenable because under U.S. Supreme Court precedent, the government may not impose 'substantial and unjustified obstacles' to a woman's exercise of her right to an abortion 'pre-viability'. ${ }^{187}$

\section{Conclusion}

The legal issues surrounding UAC are multiple and complex. The main legal issues addressed in this article cover the entire terrain of UAC apprehension, placement with a qualified sponsor or institution, detention, and departure. Federal court jurisprudence in the United States addressed issues relating to the release and detention of $\mathrm{UAC}$, including the right to be released to a private custodian, the right to due process in custody and placement decisions, and the right to a bond hearing under the Flores settlement. According to the U.S. federal courts, an unaccompanied minor does not have a fundamental right to be released to a private individual who is not his or her parent or legal custodian. On the other hand, both the parents of an unaccompanied minor and the minor have the fundamental right to family reunification. The decision of the government to withhold the minor from the custody of the parent should comply with due process. The minor and his or her parents should be granted notice and hearing to present

\footnotetext{
${ }^{185}$ ibid.

${ }^{186}$ ibid.

${ }^{187}$ ibid. 737; Planned Parenthood of Southeastern Pennsylvania v. Casey 505 U.S. 833 (1992); Whole Woman's Health v. Hellerstedt 136 S.Ct. 2292 (2016).
} 
evidence on the feasibility of family reunification and release of the minor to the parent's custody.

Case law examining the rights of UAC prior to voluntary departure emphasize the need to grant them the opportunity to consult with a responsible adult, including a lawyer from a free legal services list that should be provided to them. Also, the minor must be aware of and understand the consequences of voluntary departure prior to signing the voluntary departure form. The minor, for instance, must be aware that upon availing of voluntary departure, he or she waives the right to deportation hearing. Waiver of these rights must be knowing and intentional.

Federal courts have also tackled issues concerning asylum claims filed by UAC. These include the right of third parties to custody of the unaccompanied minor, the minority age at the time of the asylum application, and the right of the UAC to request consent for a state juvenile court's jurisdiction. In removal proceedings against UAC, federal courts have elaborated on the scope and meaning of the right to counsel and the right to a bond rehearing upon their rearrest because of allegations of gang membership. Finally, federal courts have also examined issues concerning the detention of UAC in ORR facilities. In particular, precedent applied the Farmer v. Brennan legal standard of deliberate indifference to determine whether or not detention officials and the administrators who operate the facilities can be made liable for abuses experienced by UAC. In another case, a federal court clearly granted an unaccompanied minor who had complied with all state laws on abortion, the right to terminate her pregnancy.

Our primary methodology in this article was a case analysis of all relevant cases. The article utilized inductive doctrinal analysis to identify, categorize, and analyze pertinent legal issues decided at various stages of immigration enforcement against UAC. This approach allows us to understand how federal courts have interpreted and expanded the rights of UAC but it is 
limited in understanding the political and ethical questions associated with U.S. policy on UAC and U.S. immigration policy more generally. Further research on UAC should expand our understanding of the political and ethical dimensions of U.S. policy towards unaccompanied alien children. 
2

3

4

5

6

7

8

9

10

11

12

13

14

15

16

17

18

19

20

21

22

23

24

Figure 1. Total UAC Apprehensions, Referrals, and Sponsorships: FY 2010 - FY 2017

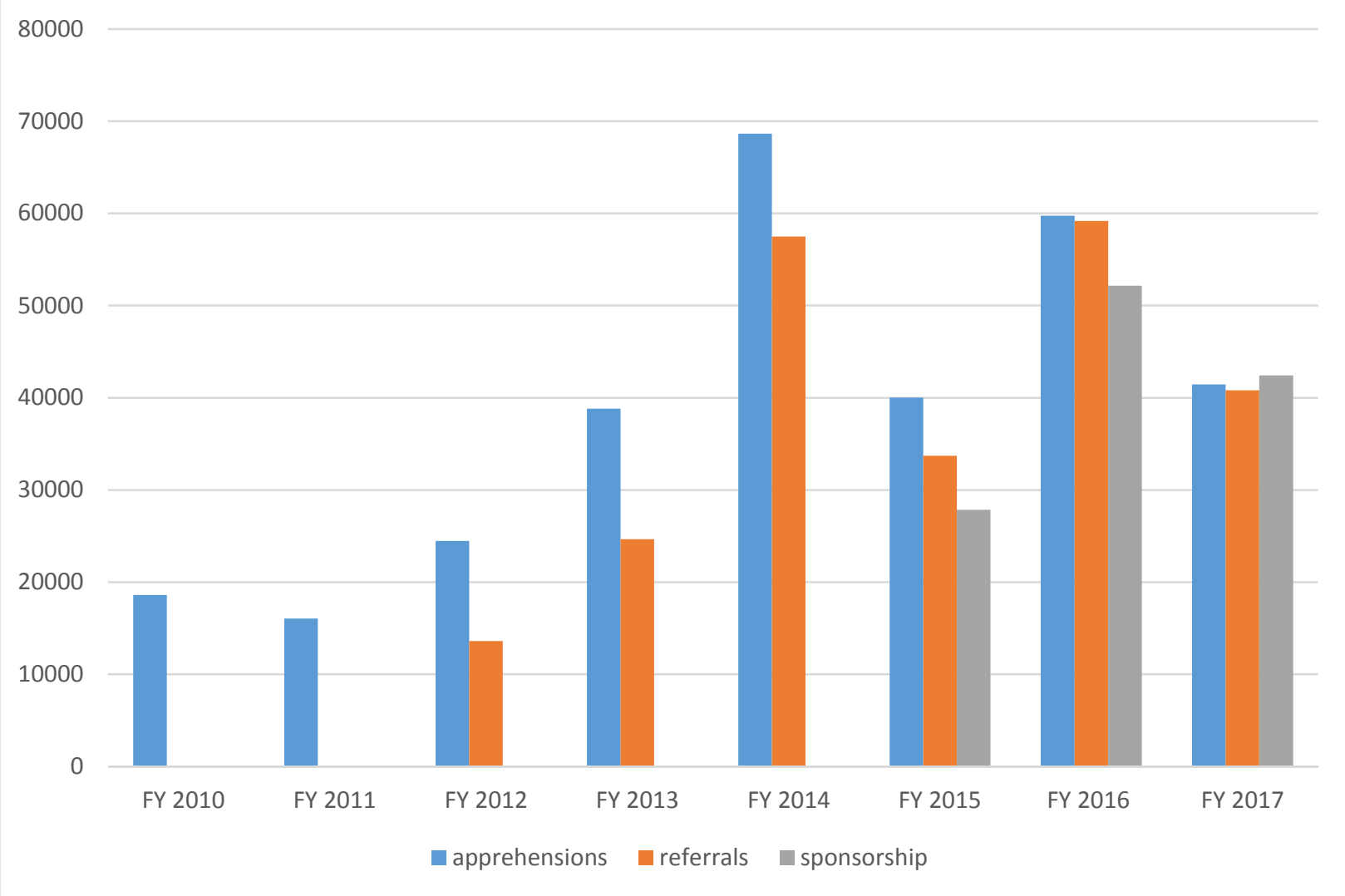


Figure 2. UAC by Country of Origin: FY 2012 to FY 2017

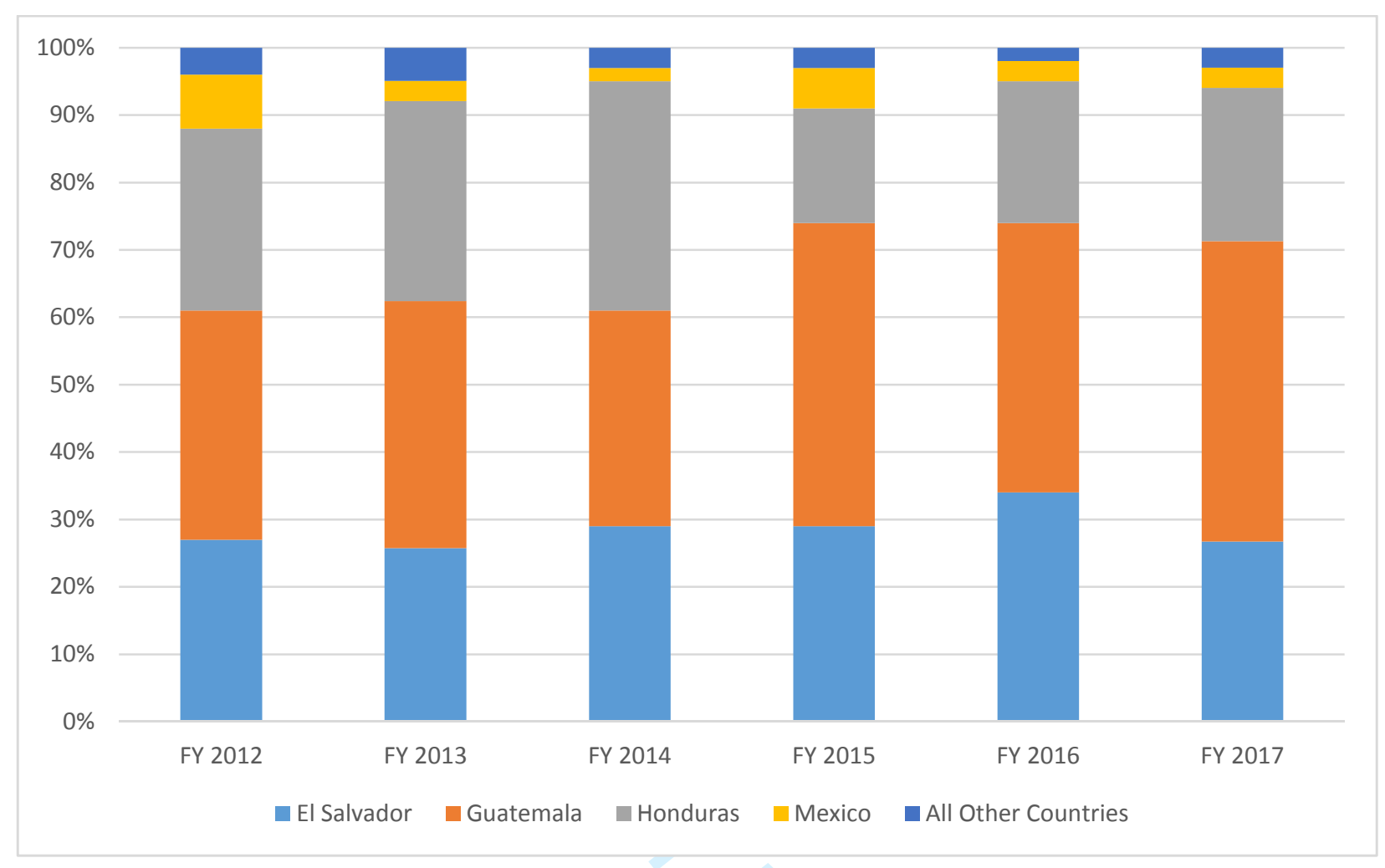

